Jurnal Abdidas Volume 2 Nomor 1 Tahun 2021 Halaman 81-85

JURNAL ABDIDAS

http://abdidas.org/index.php/abdidas

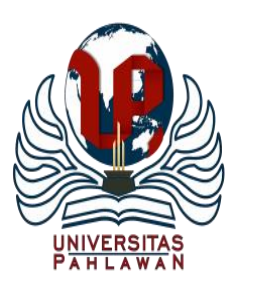

\title{
Peningkatan Pengetahuan dan Keterampilan Karang Taruna melalui Pelatihan Bantuan Hidup Dasar (CPR) pada Masa Pandemi Covid-19 di Kecamatan Kota Utara, Kota Gorontalo
}

\author{
Yusrin Aswad ${ }^{1 凶}$, Herman P. Luawo ${ }^{2}$, Samin M Ali ${ }^{3}$ \\ Prodi Keperawatan, Poltekkes Gorontalo, Indonesia ${ }^{1,2,3}$ \\ E-mail : yusrinaswad@poltekkesgorontalo.ac.id ${ }^{1}$ HermanLuawo@poltekkesgorontalo.ac.id $^{2}$ \\ SaminAli@poltekkesgorontalo.ac.id ${ }^{3}$
}

\begin{abstract}
Abstrak
Pengetahuan dalam menanggulangi penderita gawat darurat merupakan faktor yang sangat penting dalam menentukan keberhasilan pertolongan. Pandemi virus korona baru (Covid-19) yang menyebar cepat membuat orang tak lagi berani menolong sesamanya melalui sentuhan fisik meski ada yang sakit mendadak dan tiba-tiba jatuh di ruang terbuka, maka pada kondisi tersebut, peran serta masyarakat untuk membantu korban sebelum ditemukan oleh petugas kesehatan menjadi sangat penting dengan adanya pelatihan BHD pada saat Pandemi Covid-19. Tujuan kegiatan ini adalah agar meningkatnya pengetahuan dan keterampilan karang taruna melalui pelatihan bantuan hidup dasar pada masa pandemi Covid-19 di Kecamatan Kota Utara, Kota Gorontalo. Metode yang digunakan yaitu ceramah dan demostrasi, sasaran pengabdian adalah karang taruna Kec. Kota Utara dan analisa menggunakan analisis statistik pengetahuan dan keterampilan. Hasil dari kegiatan ini, adanya perubahan pengetahuan tentang BHD (CPR) dari kurang menjadi baik dan ada perubahan Keterampilan tentang BHD (CPR) dari kurang menjadi baik dengan analisis statistik analisis statistik menunjukkan bahwa nilai $\alpha$ sebesar 0,000 . Pentingnya dilakukan peningkatan pengetahuan CPR karena pada konsep CPR lama AHA 2015 masih menggunakan Bantuan Napas atau ventiklasi "mout to mout" sehingga penolong beresiko terpapar Covid-19, pada AHA 2020 untuk bantuan napas ventilasi sudah dihilangkan sehingga memperkecil kemungkinan terpapar.
\end{abstract}

Kata kunci : pandemi Covid-19, CPR

\section{Abstract}

Knowledge in dealing with emergency patients is a very important factor in determining the success of aid. The new corona virus pandemic (Covid-19) which spreads rapidly makes people no longer dare to help others through physical touch even though someone is suddenly sick and suddenly falls in an open space, so in this condition, the role of the community to help victims before being found by Health workers became very important with BHD training during the Covid-19 Pandemic. The purpose of this activity is to increase the knowledge and skills of the Youth Organization through Basic Life Assistance Training during the Covid-19 Pandemic in Kota Utara District, Gorontalo City. The method used is Lecture and Demonstration, the target of dedication, is the Kec. Youth organization. North City and analysis using statistical analysis of knowledge and skills. The results of this activity, there was a change in knowledge about BHD (CPR) from less to good and there was a change in skills about BHD (CPR) from less to good with statistical analysis. Statistical analysis showed that the a value was 0,000. The importance of increasing CPR Knowledge is because in the old CPR concept, the 2015 AHA still uses inhalation assistance or venticlation "Mout To Mout" so that the helper is at risk of being exposed to Covid-19, in AHA 2020 for breath assistance, ventilation has been eliminated, thereby reducing the possibility of exposure.

Keywords : Covid-19 pandemic, CPR

Copyright (c) 2021 Yusrin Aswad, Herman P. Luawo, Samin M Ali

$\triangle$ Corresponding author

Address : Poltekkes Gorontalo

Email : yusrinaswad@gmail.com

DOI $\quad$ : https://doi.org/10.31004/abdidas.v2i1.213

ISSN 2721-9224 (Media Cetak)

ISSN 2721- 9216 (Media Online)

Jurnal Abdidas Vol 2 No 1 Tahun 2021 p-ISSN 2721-9224 e-ISSN 2721-9216 


\section{PENDAHULUAN}

Kondisi kegawatdaruratan dapat terjadi dimana saja, dan kapan saja. Sudah menjadi tugas petugas kesehatan untuk menangani masalah tersebut, walaupun begitu, tidak menutup kemungkinan kondisi kegawatdaruratan dapat terjadi pada daerah yang sulit dijangkau petugas kesehatan, maka pada kondisi tersebut, peran serta masyarakat untuk membantu korban sebelum ditemukan oleh petugas kesehatan menjadi sangat penting (Sartono, 2011). Keadaan gawat darurat merupakan suatu keadaan klinis dimana pasien membutuhkan tindakan medis segera untuk menyelamatkan nyawa dan kecacatan lebih lanjut (118, 2015).

Ketidakmampuan dalam menangani pasien gawat darurat umumnya disebabkan oleh kegagalan mengenal risiko, keterlambatan rujukan, kurangnya sarana yang memadai dan pengetahuan dan keterampilan tenaga medis, paramedis dalam mengenal keadaan risiko tinggi secara dini yang harus dilakukan secara efektif dan efisien (Muwardi, 2003).

Pengetahuan dalam menanggulangi penderita gawat darurat merupakan faktor yang sangat penting dalam menentukan keberhasilan pertolongan kecelakaan. Kesalahan atau ketidaktepatan pemberian pertolongan pertama pre hospital dalam melakukan pertolongan dapat menyebabkan kecacatan atau kematian penderita gawat darurat. Upaya yang harus dilakukan untuk meminimalkan angka kematian penderita gawat darurat harus mempersingkat response time (Amiruddin, 2010). Salah satu indikator keberhasilan penanggulangan medik penderita gawat darurat adalah kecepatan memberikan pertolongan yang memadai kepada penderita gawat darurat baik pada keadaan rutin sehari-hari atau sewaktu bencana (Alton, 2009). Keberhasilan waktu tanggap sangat tergantung kepada kecepatan yang tersedia serta kwalitas pemberian pertolongan untuk menyelamatkan nyawa atau mencegah cacat sejak di tempat kejadian, dalam perjalanan hingga pertolongan rumah sakit (Muwardi, Materi Pelatihan PPGD,, 2003).

Di tengah wabah COVID-19, muncul satu fenomena sosial yang berpotensi memperparah situasi, yakni stigma sosial atau asosiasi negatif terhadap seseorang atau sekelompok orang yang mengalami gejala atau menyandang penyakit tertentu (Covid19.go.id, 2019). Covid-19 yang menyebar cepat membuat orang tak lagi berani menolong sesamanya melalui sentuhan fisik meski ada yang sakit mendadak dan tiba-tiba jatuh di ruang terbuka, maka pada kondisi tersebut, peran serta masyarakat untuk membantu korban sebelum ditemukan oleh petugas kesehatan menjadi sangat penting dengan adanya pelatihan BHD pada saat Pandemi Covid-19, sehingga Salah satu cara yang dapat dilakukan adalah dengan mengubah stigma dan memberikan pengetahuan pada masyarakat dalam upaya pemberian pertolongan pertama pre hospital khususnya resusitasi jantung paru saat pandemi Covid-19.

\section{METODE}

Metode yang digunakan dalam penyelesaian pelaksanaan pengabdian kepada masyarakat adalah 
dengan cara melakukan ceramah/pemberian materi berupa teori-teori terbaru mengenai CPR dan kemudian dilakukan demonstrasi oleh tim. Untuk melakukan pengukuran pengetahuan sebelumnya dilakukan pre-test baik pengetahuan dan praktek. Sasaran pengabdian adalah Karang Taruna Kec. Kota Utara sebanyak 30 peserta dengan usia rata rata kurang dari 35 Tahun. Lokasi kegiatan dilaksanakan di Aula Kelurahan Dulomo Utara dengan materi Covid-19 secara umum, materi BHD secara umum, materi CPR secara khusus saat pandemi dan evaluasi kegiatan dengan melakukan post-test pengetahuan dan praktek.

Alat dan bahan digunakan adalah pantom CPR dengan menggunakan lampu indikator kompresi. Cara kerja dilakukan dengan pengukuran pengetahuan awal atau pre-post pengetahuan dengan menggunakan google form begitu juga post test dan untuk praktek dilakukan secara manual dengan menggunakan lembar SOP baik sebelum maupaun sesudah dan kemudian hasilnya dianalisa. Data menunjukan pengetahuan baik hanya ada 2 peserta dan 6 peserta cukup dan sisnya adalah kurangdan baik hanya ada 2 peserta dan sisanya kurang. Uji statistik yang digunakan dalam pengabmas ini adalah dengan menggunakan uji statistik statistic paired t test.

\section{HASIL DAN PEMBAHASAN}

Dalam kegiatan ini untuk mencapai tujuan pengabdian masyarakat dilaksanakan sesuai Peraturan Daerah Kota Gorontalo dan petunjuk teknis pelaksanaan pengabmas oleh PPSDM Kesehatan. (PPSDM, 2018.) Selain itu karena saat ini masa pandemi Covid-19, maka tim melakukan protokol kesehatan yang ketat dimana untuk meminimalisir faktor resiko baik ke sesama peserta maupun pemateri. Untuk menjaga mutu pelatihan, TIM memfasilitasi alat peraga yang terstandar (Phantom CPR) yang menggunakan indicator lampu tepat atau tidak pada saat melakukan kompresi.

1. Ada dua indikator utama dalam pelaksanaan pengabdian masyarakat ini yang pertama adalah indikator pengetahuan. Indikator pengetahuan diukur dengan menggunakan kuisioner melalui google form yang berisi tentang konsep CPR yang dilakukan sebelum dan sesudah pelatihan. Indikator ke dua adalah keterampilan. Untuk indikator ini dilakukan penilaian dengan menggunakan lembar SOP CPR dimasa pandemik yang bersumber dari AHA baik sebelum dan sesudah pelatihan pengabmas. Hal ini sejalan dengan penelitiannya (Nuranisa, 2018) yang berjudul pengaruh pembelajaran $\mathrm{POE}$ (predict, observasi dan explanation) terhadap hasil belajar siswa SMA 1 Kota Semarang dengan hasil ada pengaruh yang signifikan terhadap pembelajaran POE.

2. Keunggulan pelaksanaan kegiatan ini adalah pertama, masyarakat dalam hal ini Karang Taruna mampu untuk merubah stigma negatif terhadap penderita maupun keluarga pasien Covid-19. Kedua, adalah anggota Karang Taruna yang mengikuti pelatihan memiliki pengetahuan dan ketrampilan BHD khususnya CPR dimasa pandemi Covid-19. 
(CPR) pada Masa Pandemi Covid-19 di Kecamatan Kota Utara, Kota Gorontalo - Yusrin Aswad, Herman P. Luawo, Samin M Ali

DOI: https://doi.org/10.31004/abdidas.v2i1.213

3. Kelemahan dalam kegiatan ini adalah dimana kegiatan ini dilakukan dimasa pandemi Covid-19 dan untuk protokol kesehatan khususnya jarak sulit dihindari disaat pelaksanaan praktek CPR. Luaran pada kegiatan ini adalah video tutorial CPR dimasa pandemi Covid-19 dan SOP CPR dimasa pandemi.

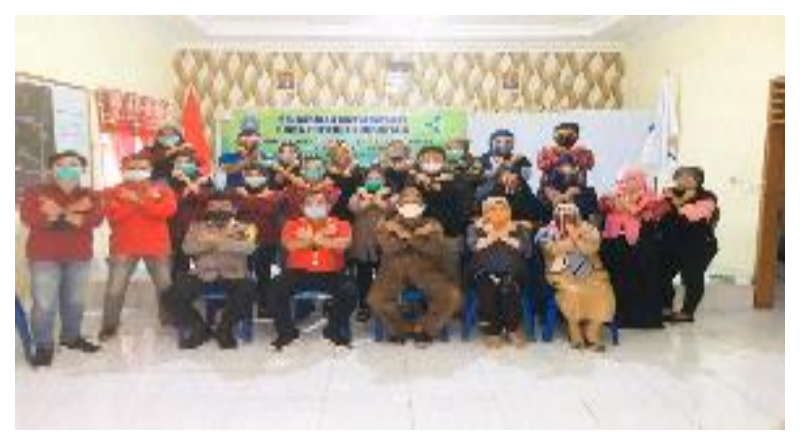

Gambar 1. Pembukaan Pelatihan

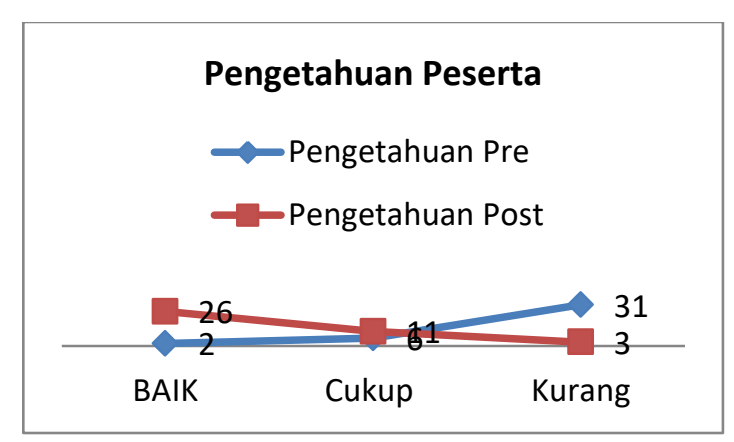

Grafik 1. Pengetahuan Peserta

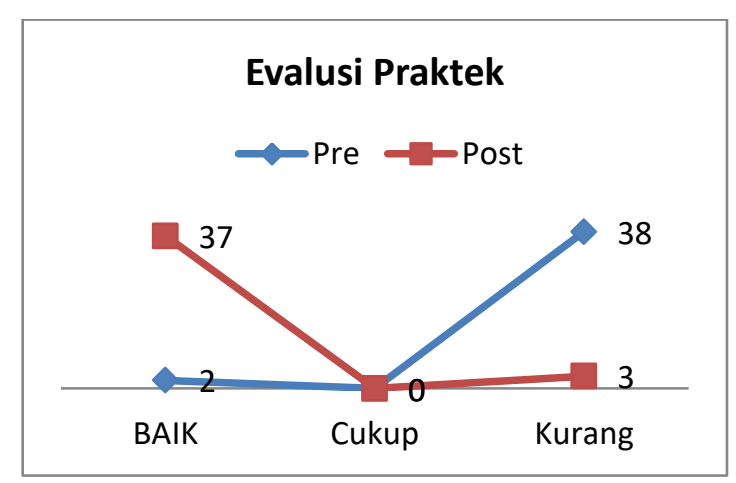

Grafik 2. Pelaksanaan Praktek

(Data Primer 2020)

\section{SIMPULAN}

Adapun beberapa simpulan dari kegiatan ini yaitu:

a. Terjadi peningkatan pengetahuan pada anggota

Karang Taruna Kelurahan Dulomo Utara Kota Gorontalo.

b. Peserta mampu melakukan Bantuan Hidup Dasar (BHD) pada korban dengan henti jantung dimasa Pandemi Covid-19.

\section{Saran}

Kepada institusi untuk dapat mensosialisasikan Bantuan Hidup Dasar khususnya CPR dimasa pandemi Covid-19 dan kepada Kelurahan untuk dapat membentuk Tim Siaga Bencana agar para Karang Taruna yang sudah dilatih dapat diberdayakan menjadi tenaga relawan apabila terjadi bencana.

\section{UCAPAN TERIMA KASIH}

Direktur Poltekkes Gorontalo yang sudah memberikan tugas untuk melakukan pengabdian masyrakat. Kepada Pemerintah Kota Gorontalo yang telah memberikan ijin untuk melaksanakan kegiatan ini. Kepada pihak kepolisian yang ikut berpartisipasi dalam kegiatan dimaksud. Kepada Karang Taruna kec. Kota Utara yang telah mengikuti kegiatan ini.

\section{DAFTAR PUSTAKA}

118, Y. A. (2015)). Basic trauma life support and basic cardiac life support [edisi 6.]. . Jakarta: .

Alton. (2009). First Aid: Pertolongan Pertama Edisi Kelima. Jakarta:: Penerbit Erlangga. 

(CPR) pada Masa Pandemi Covid-19 di Kecamatan Kota Utara, Kota Gorontalo - Yusrin Aswad, Herman P. Luawo, Samin M Ali

DOI: https://doi.org/10.31004/abdidas.v2i1.213

Amiruddin, K. (2010). Penanganan korban akibat kecelakaan lalulintas. Jakarta.

Covid19.go.id. (2019). berita/kemenkes-stigmaberkontribusi-terhadap-tingginya-angkakematian-covid-19. jakarta: Kompas.

Muwardi. (2003). Materi Pelatihan PPGD,. Surakarta.

Nuranisa, D. ( 2018). Pengaruh pembelajaran POE (Predict, observasi dan explanation) . Pendidikan.

Nurjanah, N. (2016). Peningkatan Hasil Belajar IPA Dengan Menerapkan Metode Inkuiri Siswa Kelas V SD Negeri 68 Kec. Bacukiki Kota Parepare. Publikasi Pendidikan, 107-110.

PPSDM. (2018.). Pedoman Pengabdian Masyarakat. Jakarta.

Sartono, S. \&. ( 2011). Basic Trauma Cardiac Life Support. Jakarta: : CV.Sagung Seto. 